INTERACTIVE ARTICLE COVER

RUPKATHA JOURNAL

About the Journal

\begin{tabular}{|c|c|}
\hline \multicolumn{2}{|r|}{ About the Journal } \\
\hline Journal DOI & https://doi.org/10.21659/rupkatha \\
\hline Journal Home & www.rupkatha.com $\triangle$ \\
\hline Indexed by & Scopus $\searrow$ Web of Science: Emerging Sources Citation Index (ESCI) DOAJ \\
\hline Journal Metrics & CiteScore 2020: 0.2 | SJR 2020: 0.162 | SNIP 2020: 0.193 | JCI 2020: 0.50 \\
\hline \multicolumn{2}{|r|}{ About the Issue } \\
\hline Themed issue & $\begin{array}{l}\text { Volume 4, number 1, } 2022 \text { (January-March) | Contemporary East and } \\
\text { Southeast Asian Literary and Cultural Studies }\end{array}$ \\
\hline Guest Editors & Dr Jeremy de Chavez $\triangle$ \& Dr Zhang Yue, University of Macau, China \\
\hline Issue DOI & https://doi.org/10.21659/rupkatha.v14n1 \\
\hline TOC & https://rupkatha.com/v14n1.php $\triangle$ \\
\hline Peer Review & Under the responsibility of the Guest Editors \\
\hline \multicolumn{2}{|r|}{ About the Review } \\
\hline Title & $\begin{array}{l}\text { Twenty-First-Century Children's Gothic: from the Wanderer to Nomadic } \\
\text { Subject by Chloé Germaine Buckley }\end{array}$ \\
\hline Author/s & Zhao Yifan $\otimes$ \\
\hline Affiliation & Ocean University of China \\
\hline Author ID & Not available \\
\hline Funding & Not applicable \\
\hline Article DOI & https://doi.org/10.21659/rupkatha.v14n1.25 Pages: 1-2 \\
\hline Abstract & https://rupkatha.com/v14n125 Ø \\
\hline Full-text PDF & https://rupkatha.com/V14/n1/v14n125.pdf $\oslash$ \\
\hline \multirow[t]{2}{*}{ Article History } & Complete review received: 6 Sept 2021 | Accepted: 14 Sept 2021 \\
\hline & First Published: 05 February 2022 \\
\hline Review Impact & Check Dynamic Impact $\oslash$ \\
\hline Copyright & Aesthetics Media Services $\square$ \\
\hline Licensing & Creative Commons Attribution Non-Commercial 4.0 \\
\hline
\end{tabular}

This review is published under a Creative Commons Attribution Non-Commercial 4.0 International License (http://creativecommons.org/licenses/by-nc/4.0/), which permits non-commercial re-use, distribution, and reproduction in any medium, provided the original work is properly cited. For citation use the DOI. For commercial re-use, please contact editor@rupkatha.com. 
1 | Rupkatha Journal, Vol. 14, No. 1, 2022

Book Review

\title{
Twenty-First-Century Children's Gothic: from the Wanderer to Nomadic Subject by Chloé Germaine Buckley
}

\author{
Publisher: Edinburgh University Press \\ Date of Publication: 2018 \\ Language: English
}

ISBN: 9781474430173

Reviewed by

Zhao Yifan

Ocean University of China

Children's literature has long intertwined with Gothic motifs, yet contrasting with the profound Gothic inheritance of children's literature, the relevant research remains to be a relatively new direction, which has gained increasing popularity only in recent years. As the newest monograph in the field, Twenty-First-Century Children's Gothic: from the Wanderer to Nomadic Subject brings out an exciting outlook to children's Gothic studies, tracing through a range of children's Gothic fictions between 2000 and 2015. Following Braidotti's account of nomadic subjectivity, the book's author Dr Chloé Germaine Buckley concludes that the theme of homelessness is a major concern for post-millennial children's Gothic, which does not lead to despair but positive possibilities to new lives, regarding homelessness as nomadism - a concept echoing with the nomadic ethics of Deleuze's philosophy, which expresses a process ontology that values change and motion over stability (Braidotti, 2013, p. 344).

Throughout the five chapters of her book, Buckley challenges the melancholic assumptions about children's Gothic and reconfigures a negative condition into a productive precondition: homelessness as nomadism. The reading of homelessness as nomadism is a productive interpretation that transforms a catastrophic strike into a call to adventure. She takes the recurring theme of un-homing as a nomadic playfulness. This rejection of home is-as Deleuze would put it-the rejection of sameness, the rejection of static, sterile and self-replicating life. Buckley's accounting for children's Gothic emphasizes children's subjectivity, which situates outside of a pedagogical framework. Having faith in children's power of creating their own "line of flight," Buckley regards a child as a self that is continually in the process of becoming and calls on new perspectives to account for children's Gothic, instead of dwelling in the traditional humanist concepts and ego-relational psychology.

In her innovative and rigorous analysis, Buckley disagrees with many accepted claims and demonstrates her affirmative perspective of children's Gothic, just like the post-millennial fictions she focuses on. For example, counter to the wide praise of Neil Gaiman's Coraline as the exemplary work of "'uncanny' nature of childhood"(Buckley, 2018, p. 40), she argues that it offers a new 
intertextual mode of writing in the post-millennial period, which in this case is the intertextuality between Gothic, psychoanalysis and children's fiction. And instead of Coraline, $A$ Series of Unfortunate Events by Daniel Handler (under the pen name Lemony Snicket) is the one that exemplifies this new form of Gothic writing for children, which offers a promising hope rather than an "unlikely" hope (Olson, 2010, p. 522).

Buckley's reading of post-millennial children's Gothic offers a nomadic alternative. The monograph itself can be seen as a manifestation of the rhizomatic nature of 21st-century Gothic intertextuality, weaving studies of Gothic and children's literature as well as Deleuze and Guattari's concepts together, and at the same responding to the dominant humanist and constructivist approach to children's fiction. Buckley demonstrates her ideas of homelessness as nomadism explicitly in well-written words, bringing out an exhilarating approach to Gothic and children's literature alike. Just as Buckley's intention, the book has contributed to a wider cultural and theoretical project of nomadic subjectivity, which is expressed by "emerging subjects-in-progress and new patterns of becoming" (Buckley, 2018, p. 204). However, this interpretation is only one possible mode among all the possibilities, which Buckley has made clear in her book that it is not a totalising account. Of course, there is still space for debate whether this "line of flight" is the most constructive direction free from the aporia of deconstruction since the becoming children in her interpretation remain unresolved. Besides, though the examples she chooses (including 8 fantasy novels in total) explicitly express what she has concluded, if another 8 exemplary novels were picked, it is possible to induct another central argument led by a perfectly logical chain. In the diversified and various post-modern cultures, to say homelessness as nomadism is the only trend might sound too inclusive. But what Buckley has done is to open a gateway for us to trace down and explore multiple understandings of children's Gothic.

Affirmative and generative, Buckley's book celebrates the nomadic existence of children in twenty-first-century children's Gothic, initiating a viewpoint of nomadic subjectivity. Being willing to engage with difference and otherness, Buckley is a mobile and active subject herself. Readers can easily sense her passion for studies of Gothic and children's literature in her book, which can be a good reference for those who share the same passion, for it provides a promising nomadic perspective and allows readers to review traditional approaches through her introduction and confrontation with a range of fundamental works in the related field for beginners to refer to.

\section{References}

Braidotti, R. (2013). Nomadic Ethics. Deleuze Studies, 7(3), 342-359

Buckley, C. G. (2018). Twenty-First-Century Children's Gothic: from the Wanderer to Nomadic Subject. Edinburgh: Edinburgh University Press. 40+204

Olson, D. (2010). The Longest Gothic Goodbye in the World: Lemony Snicket's A Series of Unfortunate Events. In D. Olsen (Ed.), 21st-Century Gothic: Great Gothic Novels Since 2000. MD: Scarecrow Press. 522

Zhao Yifan, a PhD candidate at the Ocean University of China, is especially interested in studies of children's literature with dark motifs and its translation. 